\title{
Biographical learning: two decades of research and discussion
}

\author{
Anders Hallqvist \\ Linköping University Post Print
}

Tweet

N.B.: When citing this work, cite the original article.

This is an electronic version of an article published in:

Anders Hallqvist, Biographical learning: two decades of research and discussion, 2014, Educational review (Birmingham), (66), 4, 497-513.

Educational review (Birmingham) is available online at informaworldTM:

http://dx.doi.org/10.1080/00131911.2013.816265

Copyright: Taylor \& Francis (Routledge): SSH Titles

http://www.routledge.com/

Postprint available at: Linköping University Electronic Press

http://urn.kb.se/resolve?urn=urn:nbn:se:liu:diva-96747 
Biographical learning: Two decades of research and discussion

Anders Hallqvist, $\mathrm{PhD}$

Linköping University

58183 Linköping, Sweden

+4613285890

anders.hallqvist@liu.se

Submitted on the 24 of April 2013 


\title{
Biographical learning: Two decades of research and discussion
}

\begin{abstract}
The article discusses the concept of biographical learning and reviews previous research on the subject. Several tensions between different versions of the concept are recognized, and a wide range of research areas in which the concept has been used are identified and presented. The general idea in the biographical learning tradition regarding the occurrence of general conceptions of one's biography, as well as the idea of narrative coherence, is discussed critically. New areas of research are suggested.
\end{abstract}




\section{Introduction}

In the early 1990s, the sociologist Peter Alheit introduced the concept of biographical learning in adult education research. It is closely related to a methodological approach that endorses the use of autobiographical narratives in this field of research (Alheit, Bron-Wojciechowska, Brugger, \& Dominicé, 1995; Antikainen \& Komonen, 2003), and to the re-emergence of biographical methods in the social sciences generally (Chamberlayne, Bornat, \& Wengraf, 2000). Further, it is related to a particular educational practice that harnesses autobiographical storytelling (Dominicé, 2000) and follows the belief that adult education in particular needs to take people's life experiences as a point of departure. Representing an alternative configuration of lifelong learning, intending to increase knowledge about 'the relation between individual biographies and institutions of adult education', the 'biographical approach' is said to provide a 'new horizon' for adult education research (Lischka, 1995, p. 9).

An important arena for discussing biographical learning has been the Network on Life History and Biographical Research, a part of the European Society for Research on the Education of Adults (ESREA). The network bears witness to the new interest in biographical research approaches (Bron \& West, 2000; West, Alheit, Andersen, \& Merrill, 2007) emerging during the 1990s in the field of adult education. This 'revival' (Dominicé, 2000) of biographical approaches is 'part of a broader trend across the social sciences' and a 'reaction against forms of research (...) which tended to marginalize the perspectives and subjective experiences of learners themselves or reduced subjective processes, including learning, to overly abstract entities' (West, et al., 2007, p. 12). In the context of this network, the concept of biographical learning was launched in close connection to the network meetings in Geneva in 1993 and Vienna in 1994. One outcome of these conferences was the edited book The 
Biographical Approach in European Adult Education (Alheit, et al., 1995), where we find some of the early English texts on the subject. ${ }^{1}$

With respect to methodology, biographical approaches in adult education research are said to reach back to the Chicago School of the 1920s (West, 2010, p. 25). Connections are often made to the life history methodology and the works of Thomas and Znaniecke (1918) (cf. Dominicé, 2000). However, the past decades have witnessed a considerable expansion in biographical research (Chamberlayne, et al., 2000) and even more in the closely related area of narrative research (Horsdal, 2012; Hydén, 2008; Mishler, 1995). In the latter, works written by Bruner (Bruner, 1986, 1990) and Sarbin (Sarbin, 1986) are often referred to as canonical and as turning points. Narrative is considered as a 'mode of thought' that is fundamental to the creation of meaning. The use of biographical interviewing as a research method when studying biographical learning points out that the stories people tell are a source of information regarding the way people view their life history. However, the concept of biographical learning also points to the learning potential of autobiographical storytelling.

One important claim made in the early publications on biographical learning is that biography has become 'a field of learning' and that this is because of changes in society generally.

'Living a life' thus appears to be a more problematic undertaking than in the past. Traditional biographical designs are looking less appropriate. Biography itself has become a field of learning in which transitions have to be anticipated and coped with ... Biographies are becoming more complicated, more individual, less 'normal', but at the same time more colourful, autonomous and self-willed. Life course seems to be turning into a 'laboratory' where we must develop skills for which there are at first no 'curricula'

\footnotetext{
${ }^{1}$ The German discussion on the subject is extensive, and there are related discussions within Frenchspeaking countries and in other speech communities. The present review covers only articles written in English however.
} 
(cf. Dominicé 1990). This represents, without any doubt, a special and specific challenge for adult education. (Alheit, 1994, p. 285)

A main point in this quotation is that autobiographical reconsiderations are becoming more important in our time and that this is because people no longer follow standardized life trajectories. A similar point is made by career researchers, pointing to the spread of 'protean' biographical patterns (cf. Hall, 1996, 2004). The arguments resemble the individualization thesis stressed by Giddens, Beck, Bauman, and others. According to this, identity is being transformed from a 'given' to a 'task' (Bauman, 2000, p. 31). The development of the concept of biographical learning thus is related to a particular way of describing the current sociocultural conditions. Probably it could be seen in the context of Giddens's (1991) call for 'life politics':

Life politics concerns political issues which flow from processes of self-actualisation in post-traditional contexts, where globalising influences intrude deeply into the reflexive project of the self, and conversely where processes of self-realisation influence global strategies (p. 214).

Recognizing the weakening of the traditions' power of influence, Giddens places the individual's lifestyle and decision making at the centre of policy. In a similar manner, the notion of biographical learning attempts to make education policy recognize the potentiality of people's autobiographical reflections and storytelling.

Clearly, speaking about lifelong learning as biographical learning differs from a view in which political and economic precepts frame lifelong learning. Instead, biographical learning is said to be concerned with 'the individual side of lifelong learning', focusing on 'the learning processes of individual social actors' and taking as a starting point 'the life history perspective of the actual learner' (Alheit \& Dausien, 2002)@5,11). Based on a broad sociocultural analysis as well as on the intention to understand individual learning processes, the 
concept thus provides an alternative way of addressing issues related to policy making (eg. Alheit \& Dausien, 2002; Glastra, Hake, \& Schedler, 2004).

The concept of biographical learning is attractive partly because of its holistic character, including both formal and informal learning processes, binding emotional, existential and cognitive aspects, and uniting preconscious and conscious dimensions. It has been used for quite a while now, however, but even though many researchers have written on biographical learning, there has been no attempt to review what hitherto has been done on the subject. The aim of this paper is to provide such a review, including both conceptual contributions and empirical ones. In the first section, I will describe the main ideas and the conceptual discussion and development following from those. Thereafter, the variety of application efforts, in which the concept has been brought in to different empirical fields, will be presented. Based on this, I will then point to some areas and conceptual issues that could be important to address in new studies.

\section{Conceptualizations of biographical learning}

While beginning with the early English texts from 1994, the following presentation of the concept and its interpretations will centre on the main and explicit definition provided by Peter Alheit and Bettina Dausien in 2002. Several outlooks and comparisons to related works will be made. The readers will thus find themselves moving there and back, and returning to the mentioned definition. I will amplify dissimilarities but reduce the number of them, to be able to present some main tensions in the different versions of biographical learning present in the literature.

\section{Learning processes within transitions}

The first English article that uses both the term and the concept biographical learning was originally a lecture given in Geneva in 1993 at the above-mentioned conference. In the next 
year it was published (Alheit, 1994) and in the year thereafter it was republished in an edited book (Alheit, et al., 1995). Surprisingly, in the original text, the term 'biographical learning' occurs only once (Alheit, 1994, p. 293). Instead, the author uses other labels, for example, 'transitional learning processes' and 'learning processes within transitions', and combinations like 'biographically oriented learning' and 'a biographical approach to learning'. However, the particular combination 'biographical learning' gained a more prominent position because it was included in a new title when the manuscript was republished (with no other obvious revisions besides the new title) in the mentioned book (Alheit, 1994).

Opposing an existing 'therapeutic paradigm' in adult education, ${ }^{2}$ the author places confidence in the competence of individual learners to handle biographical disruptions caused by late modernity. In short, people cope with change by developing new ways of understanding the relation between their lives and the particular world in which they live. They produce new 'life constructions' (p. 288), which means that they 'organize' their biographies in such a way that biographical resources are related to the context in which they live. This learning process causes a change in people's 'self- and world referentiality' (Alheit, 1994, pp. 289, 291), and because of the new life constructions, 'social actors take a different stance towards themselves and the world in general' (p. 293). According to this first version of biographical learning, the concept thus signifies a learning process that affects the ways in which people understand the relation between themselves and the world. It presupposes an ability to 'redesign again and again, from scratch, the contours of our life within the specific contexts in which we (have to) spend it, and that we experience these contexts as 'shapeable' and designable' (Alheit, 1994, p. 290). This ability is termed biographicity, and the biographical learning process — that is, the organizing of experiences_-presupposes 'selfreflexive activities' (Alheit, 1994, p. 290). The term 'transition', which occurs several times

\footnotetext{
${ }^{2}$ Probably the author addresses a particular German discussion here (cf. Alheit, 1992).
} 
in close connection to the concept of learning, is used to point out that, in biographical learning processes, new knowledge is located within a framework that is changing. It is not related to 'existing structural contexts' but interpreted 'as an element of new contextual conditions' (p. 65). A reference to Peirce points out that this is a matter of creativity: biographical learning is about networking something that 'we would never previously have dreamed could be combined' (Alheit, 1992, p. 290). New knowledge concerning the relation between individuals and the world thus emerges when people, situated within a changing environment, reflect on themselves and their biography.

\section{Action and sense making}

In the first explicit and most cited definition, which gives the impression of being 'all inclusive', biographical learning is said to be

a self-willed, 'autopoietic' accomplishment on the part of active subjects, in which they reflexively 'organise' their experience in such a way that they also generate personal coherence, identity, a meaning to their life history and a communicable, socially viable lifeworld perspective for guiding their actions (Alheit \& Dausien, 2002, p. 17)

Describing the assumed outcome using expressions like 'personal coherence', 'identity', 'meaning to life history', and a 'socially viable life world perspective' that can 'guide people's actions', the results of biographical learning are presented as the counterpart to the challenges related to individualization. Further, the 'organizing' of one's experiences is said to be 'reflexive'. This attribute is related to the individualization literature, too, suggesting that people reflect not only about events and social conditions but also about themselves. In short, by 'organizing experiences' reflexively by making stories about one's life course, people learn through biographical learning new ways of viewing their lives. And as a possible outcome, new action options are opened up. 
In this definition, both thinking and acting are involved, although action is seen again as secondary to the 'organizing' of experiences. Another contribution on learning and biography by the same author (Alheit, 1999) leaves out the term 'biographical learning' altogether but the concept is at hand. In this article, the empirical basis is more at the front and, most important, there is a new emphasis on action. If the 1994 article was preoccupied with 'life constructions', now the focus is on 'coping patterns'. The new emphasis can be seen in expressions like ‘biographical action', 'biographical activities', and 'action environments'. There is no necessary contradiction here, because in the 1994 article, 'self reflexive activities' are supposed to 'shape social contexts' (p. 290) and make people 'take a different stance towards themselves and the world' (p. 293), but still there is an emphasis on the broader concept of action and not mainly on sense-making activities as 'organizing experiences' or 'life constructions'. One main tension between different versions of biographical learning thus concerns the position of action and the relation between thinking and acting. Taking this tension as a point of departure, and attempting to 'expand' conceptualizations of biographical learning that centre on individuals' reflexive efforts, Hallqvist, Ellström, and Hydén (2012) suggest that biographical learning should be considered as comprising both reflexive identity work and creative action. Believing that biographical learning processes vary continuously with respect to the relative weight and character of reflexivity and creativity respectively, Hallqvist and colleagues provide a space for recognizing diversity in biographical learning. By using 'creative action' and 'reflexive identity work' as two separate axes, four kinds of biographical learning are presented. The primacy of reflection and reflexivity in biographical learning thus is challenged in the sense that reflection does not necessarily precede concrete operations when people make efforts to change their lives. Sometimes the order of priority is reversed. Moreover, the relation between action and reflection is considered as rather loose, 
which means that people sometimes act with no reflection (or contrary to their reflections) and sometimes reflect and make decisions with no concrete operation.

\section{Learning about one's life}

Providing a clarifying distinction, Biesta and Tedder (2007) define biographical learning as 'learning about one's life and learning from one's life'. The article focuses on agency and learning, and points out that people sometimes learn about their own 'agentic orientations' and that this has an effect on their agency. A related paper (Tedder \& Biesta, 2007) instead engages with the other link in the definition and inquires into the ways in which people learn from their lives. This kind of learning refers to something quite general, namely, that learning is 'more than the acquisition of qualifications through participation in formal education' ( $\mathrm{p}$. 33). Other labels that refer to the same object could be 'experiential learning' or 'informal learning'. The article points to certain conditions that enable people to learn from their lives: spaces for reflection, analytical tools (gained, e.g., through formal education) for reflecting on life experiences, and significant others who allow people to retell their life stories. Holding together both links, the double definition provided by Biesta and Tedder claims that in biographical learning, learning and biography are intertwined: biography is both used and changed when a process of biographical learning proceeds. The particular idea of 'organizing experiences' is not present in these texts, however. Rather than producing coherent autobiographical accounts, which helps people to making sense of their life course, people learn by reflecting on the way in which they live and act. And by doing this, they learn about their agentic orientations. The tension between Biesta and Tedders's version and Alheit and Dausien's (2002) notion of 'organizing experiences' concerns whether biographical learning is about learning general views of one's life history or learning about one's particular action patterns (e.g., agentic orientations). 


\section{Conscious reflection and a surprised learner}

Parts of Alheit and Dausien's explicit definition from 2002 cited above resembles the 1994 article, but the authors further develop the attribute 'self-willed', which, in the early article, occurs only in passing. Alheit and Dausien write:

Biographical education and training processes operate in self-willed ways, they permit unexpected experiences and surprising transformations that in many cases are not foreseen by the 'learner' himself, or are not 'understood' until after the event, but which still pursue their own 'direction'. Terms such as 'seeking movement' or 'diffuse directedness' are more appropriate here than cybernetic models involving some welltargeted 'self-management' that for its part is oriented to institutionalised pre-givens. (2002, p. 16)

The generous use of quotation marks makes a reader insecure, wondering if he or she attaches the proper meaning to the words or if perhaps the author uses the words with a particular connotation. Obviously, however, 'self-willed' does not refer to the individual's self or will, but the process is the proper subject: the process of learning is said to operate on its own and people's possibilities to affect intentionally the process and its outcome are said to be restricted. Clearly there is another tension here (not necessarily contradictory) between, on the one hand, the idea of individuals as deliberately reflecting on their biography and becoming aware of new action options and, on the other hand, the surprised learner who does not understand until afterwards but follows a learning process that is self-operating and governed by a logic of its own. The latter is underscored also by the notion of 'autopoiesis' (Alheit, 1994; Alheit \& Dausien, 2002). This concept (which is used previously by the sociologist Niklas Luhmann and originally developed by the biologists Humberto Maturana and Francisco Varela) indicates that the process is characterized by self-regulation and suggests 
the individual's creative adaption to the environment (Chamberlayne, 2004). Self-regulation means that the learning individual does not govern the learning process, then, but that an internal logic fuels and directs the process. Equally important is the idea of creative adaption, emphasizing that people are not structurally determined but 'ha[ve] creative scope', engaging in the dialectic between subject and structure (Chamberlayne, 2004, p. 24).

\section{Social world as context and content of the learning process}

Making further comparisons between the concept as described by Alheit (1994) with the definition provided by Alheit and Dausien (2002), one observation concerns the expression 'self- and world-referentiality', which obtained a central position in the 1994 article but is completely missing in the 2002 article. Instead, the definition focuses on the efforts in which people make sense of their life course. Still representing a relational view on learning, Alheit \& Dausien speak of the 'sociality of biographical learning' (2002, p. 15f), however this notion concerns the context of learning, whereas 'self and world referentiality' concerns the content of the learning process. Because it is impossible to create meaning in one's life history without including the social world in the narrative, this is again a question regarding where to put the emphasis. Still one may ask if biographical learning concerns mainly the ways in which people understand the relation between themselves and the world or if biographical learning concerns the ways in which people understand their biography. This is another tension that I would like to point out. There is probably a variety in biographical learning processes regarding precisely the ways in which people include the social world in their life stories.

Can stories change structures? 
The different versions presented above presuppose a view according to which individuals are not determined by social institutions but are engaged, actively coping with biographical challenges. In this sense, biographical learning imagines a 'capable' individual who relates to the past creatively (cf. Kristensson Uggla, 2008). Alheit (1999) refers to empirical findings showing that because life changes or life transitions occur frequently in late-modern society, people do not inevitably panic (p. 75), but rather seem to be capable of dealing with them. Using various strategies of action, people act to change their own life and biography as well as the social world in which they live, 'rebuilding' their action environments. This confidence in agency and creativity has not been left without objections, however. Glastra, Hake, and Schedler (2004) for example, raise some vital questions regarding the somewhat overoptimistic character of biographical learning. First, the authors point out that there is an assumption that biographicity is something good, which self-evidently must not be the case. Second, they argue that the concept understates the power of structures over individual lives, and, thus, they raise the rhetorical question of whether 'stories' really have the potential to change 'structures'. Paving the way for their own alternative conceptualization of lifelong learning, the authors conclude that the biographicity approach runs a risk of making people adjust only passively to the individualization process, and thus they emphasize the need for meso-level arrangements, to link biographical learning with structural conditions.

Also addressing the question of the power of social conditions, Herzberg (2006) tries to make the biographical learning concept and Bourdieu's notion of habitus cast light on each other. The former is used to explain the transformation of habitus that is observed empirically: by 'reflexively drawing on one's own biographical resources of meaning' (p. 40), habitus can be transformed. Conversely, the latter is used to understand people's approaches to biographical learning. Considering 'habitus' as a construct that operates and emerges 'between the two poles of "subject" and "structure", the author recognizes people's cognitive 
capacities and sense-making efforts. Suggesting a concept of 'biographical learning habitus' (p. 40f), operationalized into measurable items (educational aspirations, coping strategies, interpretation sovereignty, value orientations, and biographical reflexivity) in the study, intergenerational changes in 'biographical learning habitus' are observed. The author emphasizes the enduring power of social conditions, why intergenerational changes in habitus are explained by referring to changes on the macro level: 'changes in the learning habitus passed on within the family in the course of the process of the transformation of society' ( $\mathrm{p}$. 45). Even though the author suggests educational arrangements as 'spaces for reflection' that take into account the productivity of reflexivity, Herzberg seems to operate within the habitus concept, rather than in the biographical learning tradition. If the concepts of biographicity and biographical learning aim at conceptualizing change, agency, and creativity, to cling to a notion of habitus seems to go back to square one.

\section{A narrative approach to biographical learning}

Following Alheit and Dausien's explicit definition of biographical learning as a reflexive organizing of one's experiences suggests a view according to which people deal with the challenge of change and transitions by autobiographical identity work. This idea of connecting self or identity with narrative and storytelling emerged in the 1980s in the field of narrative psychology (Bruner, 1986, 1990; Mishler, 1999; Sarbin, 1986). However, it has become a central issue not only in psychology but in the social sciences generally, addressed by social philosophers such as Taylor (1989), Giddens (1991), Ricœur (1992), and Honneth (1995). Viewing biographies not only as a result of living but also as a product of sense making and narrative is clearly not the point made by the mentioned authors; this is obvious to any writer of biographical accounts. The point is rather the recognition of autobiographical reflection and storytelling as salient to the individual's own life and sense of self. Although 
there are no references to the tradition of narrative psychology in the early works of biographical learning, it shows up later on (Alheit, 2005). The biographical learning concept thus resembles an idea that stresses the role of narrative and narration in the establishment and maintaining of personal identity.

However, even though the authors implicitly (Alheit, 1994) and explicitly (Alheit, 2005) make connections to narrative psychology, most research using the concept of biographical learning has not really carried out narrative analysis. In the last few years, however, researchers have suggested narrative approaches to biographical learning. Using narrative theory to further develop the concept, Biesta and Tedder (2008; cf. Tedder \& Biesta, 2009) suggest 'a narrative perspective' on biographical learning. Doing this, the authors do focus not on the story but rather on the process of storytelling, arguing that this is an important part of biographical learning. Discussing methodological issues, Stroobants (2005) also points out that a biographical interview may indicate previous biographical learning but at the same time introduce and further a new biographical learning process because the act of storytelling itself is a learning process. With the same intention, Hallqvist and Hydén (2013) introduce a narrative 'approach' to biographical learning, meaning an approach that 'considers autobiographical storytelling as a practice through which claims about life history are performed and negotiated'. Because narration can be seen not only as the outcome of a learning process but as 'learning-in-action' (Biesta \& Tedder, 2008; cf. Tedder \& Biesta, 2009), it is important to examine narration as a practice through which people negotiate meanings and make claims about life history. Narration rather than narratives is the main interest here, researchers believing that the practice of storytelling has an impact, not only on the listener but on the storyteller too. Research has, for example, drawn attention to the risk (or possibility) of being 'caught' in a story (Goodson, et al., 2010; Tedder \& Biesta, 2009a). 
Narrative approaches to biographical learning recognize the significance to learning of various narrative strategies used. For example, it has been suggested that evaluating as a part of storytelling (Labov (1972) can be regarded as reflexivity-in-practice and that people make use of different evaluative strategies when making autobiographical narratives (Hallqvist \& Hydén, 2012). Sometimes people make explicit and marked evaluations, while on other occasions, people tell stories with almost no evaluations at all. In addition, people make the evaluation from different social and temporal positions; they use direct or indirect speech and use different frameworks (such as political, existential, and juridical ones). The variety of evaluative strategies suggests that there are different kinds of reflexivity as part of the process of biographical learning. This implies an expansion of the concept of reflexivity: people may be reflexive to different extents and in different ways. To engage further with these questions and to elaborate further on the interrelationships between biography, narrative, and adult learning remains a conceptual challenge.

Narrative approaches to biographical learning can be regarded as recognizing the social and cultural 'situatedness' of biographical learning because storytelling is practiced with other people in relation to culturally established values. The narrator and the audience compose the story jointly, and whether a story will 'count' depends on its micro- and macro-sociocultural conditions. In this way, the storyteller's strong and weak ties have an impact on the story told and on how it is told. With the recognition that autobiographical storytelling is a narrative practice, social context is accentuated and considered to exist through 'social practices' (Biesta, 2009, p. 70). In the next step, the rhetorical strategies used, as well as the composition of the story, will affect the learning process. For example, the social conditions in which a story is told will influence whether an evaluation will be a marked an explicit one or if the account will have the character of an 'objective', 'neutral' report instead. 


\section{What is behind the life story and what is in front of it?}

Narrative approaches to biographical learning thus focus on explicit life stories and their production. As a contrast, in the 'original' version of biographical learning (Alheit, 1994), there is an emphasis on implicit and unthematized configurations of one's life. Referring to a particular concept labelled 'unlived lives', the author argues that there are latent opportunities, vague intentions or ideas about one's life that have not been put into practice (Alheit, 1994), that our biography carries a 'surplus' of meanings and this is why there are many ways to understand and live one's life:

Within the framework of a restricted modification potential, we have more opportunities than we will ever put into practice. Our biography therefore contains a sizeable potential of 'unlived life'. (p. 288)

The notion of unlived lives recognizes vague ideas, opportunities, or conceptions about one's life that are not yet made explicit and not 'implemented' (Alheit, 1994, p. 289). Following this line of thought, the main issue in the learning process is to 'identify' (p. 289) or 'decipher' (p. 290) the surplus meanings of our biographical knowledge and to 'appropriate them' (p. 289). This is to 'perceive the potentiality of our unlived lives' (p. 290). By the notion of 'unlived lives', the emancipatory power of biographical learning is emphasized. The unlived lives possess 'socially explosive force' and the potential to change social structures (1994, p. 289). To get hold of this force, we need to recognize and bring into the learning process not primarily conscious, explicit knowledge, but pre-reflective, unthematized configurations of our life. This final tension between different conceptualizations of biographical learning concerns whether the potential for biographical learning is related to people's rhetorical efforts or if the potential is related to unthematized configurations of people's lives. This distinction touches a main 'turn' in the history of hermeneutics that 
concerns whether the interpreter searches for 'an intention hidden behind the text' or 'a world unfolded in front of it' (Ricœur, 1991, p. 292).

\section{A variety of empirical fields}

\section{Youth studies}

In the field of youth studies, Diepstraten and colleagues (2006) incorporated the concept of biographicity into a framework aimed at understanding and analysing prototypical biographies among young people, showing how they 'learn and live' in late modernity (p. 177). While often biographical approaches to learning are viewed as a counterpart to utilitarian theories of lifelong learning that focus on people's ability to innovate and respond to change (Field, 2010, p. 91), Diepstraten and colleagues (2006) try to combine them, pointing to gains and weaknesses in both discourses. Although questioning the application of the individualization thesis among the younger ages, arguing that 'institutional forces and logic are traditionally powerful in the paths taken in primary and secondary school' (p. 189, cf. Glastra, et al., 2004), the study recognizes the significance of 'biographicity' among young people. It points to the strategies by which individuals, continuously, on a short-term basis, depart from environments that threaten their autonomy, to 'bridge the development of an integrated self-concept and life concept and the actual process of living this concept' (p. 189). Doing this, they draw biographical lines 'from lived experiences to new and upcoming ones and monitoring the fit of what they (will) do with their "most inner core"" (p. 189). However, biographical approaches are said to be off target in some respects. Most important, the study considers the significance of social networks as something overlooked. In sum, the study points to the relation between life conceptions, social capital, and the competence of biographicity. 
Looking at young retail and motor vehicle apprentices, Brockmann (2010) finds biographical learning becomes a resource that allows research to challenge common stereotypes of apprentices as 'failures or second-chance learners' (p. 71) and instead recognizes their engagement and active choices. Further, the concept points to the significance of informal and non-formal learning experiences as important to the development of meaning and (occupational) identity.

Using autobiographical storytelling as a didactic method in physical education, Christensson (2007) discusses students' perception of this and, more generally, the role of communication and reflection as part of physical education. Results showed, for example, that the method fostered an awareness regarding identity issues related to people's engagement in sports. Further, the author argues that 'the learning of skills and the acquisition of experience always include a communicative and reflective element, which responds to the biographicity and experiences of the learner' (p. 20).

\section{Higher education}

Comparing universities and adult learners around Europe, Merrill and Alheit (2004) discuss national access policies and individual practices among 'non-traditional' adult university students. The main conceptual framework is from Bourdieu, but the concept of biographicity is introduced and said to provide a theoretical link that helps understand 'the interdependence of education, transition and biography' (p. 153). The paper points to differences between institutions and countries in terms of access to higher education, and the main findings concern the variety of adults returning to education. The authors identify five different individual journeys or biographical patterns, and the paper concludes by pointing to the significance of people's biographies to their present educational experiences. Institutional factors are considered as important, but the authors emphasize the individual's 'biographical patterns', meaning that different individuals use different strategies when dealing with the 
challenges of returning to education. Thus, the authors differentiate between people using different patterns of action, categorizing individuals as 'patchworkers', 'climbers', 'integrators', 'emancipators', or 'careerists'. The distinctions resemble those described by Alheit (1999). The way in which people participate and succeed thus depends on their biographical pattern but also on 'the type of habitus and social capital they bring with them' (Merrill \& Alheit, 2004, p. 161).

Looking at distance students taking part in a 'creative writing' course, Prescott (2011) looked at learning outcomes of 'life writing' in the context of higher education. Although autobiographical writing was made a vital part of this study, the point of departure was a distinction between cognitive and affective learning processes that probably would be difficult to uphold from a biographical learning point of view. The main conclusion, however, would be in accordance with the idea of biographical learning, because the author suggests a close relation between 'affective learning' and 'cognitive learning' and points to the value of imagination and creativity in academic study 'as the prevailing ethos of higher and continuing education shifts further and further towards an instrumentalist view of learning' (p. 156).

In the area of professional sports coaching, the biographical learning concept has been used to understand the development of professional expertise among elite coaches (Christensen, 2011). Making a distinction between 'mediated' (e.g., formal coach education) and 'unmediated' (e.g., discussions with peers/workplace learning) and 'internal' (i.e., reflection/interpretation) learning situations, the author shows how the distinctions are blurred because people make use of material from a variety of situations when they organize their biographies. The article emphasizes the significance of 'breathing spaces' by which individuals may be able to reconsider and reinterpret their experiences to promote biographical learning. 


\section{Social pedagogy}

Zeller \& Köngeter (2012) discussed the relation between biographical learning and academic education among children and youth in out-of-home care. A point of departure is a broader view on learning present in the German context, suggesting that 'social pedagogy' encompasses 'all elements of living and learning as one unified process of developmental change and growth' (p. 1191). This is a marked contrast to Anglo-Saxon studies that point to 'academic underachievement' among children in out-of-home care. Developing an integrated approach that includes learning in different areas of life ('both school and care'), the study concluded that biographical crisis during childhood can be an obstacle to school attendance (not very surprising) and that, due to a biographical learning process, education can be 'successfully resumed' (p. 1194). By integrating the two areas of research, using a broader concept of knowledge, the study revealed important connections between different areas of life and different but related learning processes. The authors also call for 'biographical sensitivity among professionals who work with children in care 'given that improvements in academic achievements are closely connected with biographical learning processes' (p. 1195).

At the other end of the life span but still in the field of social pedagogy, the concept of biographicity has been used to understand the process of aging (Fristrup, 2012), to put an emphasis not on the biological age but the 'poetics of growing old' (p. 68). The authors recognize that in the process of social categorization, certain categories provide certain subject positions and that it is possible for people to reflect upon and reject those if necessary. Thus, people 'take up, ignore or resist' certain ideas and norms related to aging, 'learning to live with and by social categories of aging and old age' (p. 68). In this way, the authors suggest 'a new articulation of the social-pedagogical approach to aging' (p. 85). 


\section{Gender studies}

Suggesting that biographicity could be connected to a notion of gender competence, Stauber (2006) applied the concept to illuminate youths' transitions from school to work, recognizing that these have 'a gendered character' (Stauber, 2006, p. 64), and that when girls pass from education to the labour market, 'educational advantages turn into disadvantages':

[T]heir educational achievements do not pay off to the same extent as do those of their male competitors but, on the contrary, produce a worse position. (p. 65)

Using a 'doing gender' perspective, Stauber attempts to connect the concept of biographicity with a notion of 'gender competence', arguing that reflexivity is a common feature and that 'gendered knowledge' belongs to the domain of biographical knowledge: biographicity is about people's ability to reflect on and transform 'intersubjective knowledge, to which all kinds of gendered knowledge belong' (p. 68). 'Gender competence', further, is defined as learning to handle contradictory demands in male and female life courses, to decode gendered ascriptions, and to deal with them, not only by using them but also to refusing them in order to construct one's own gender identity. (p. 68)

Emphasizing that biographical methods illuminate the link between individuals acting and social conditions, the author explicitly brings gender into the concept of biographical learning, although recognizing that still other dimensions of social positioning should be included. The study showed how biographical and gender competencies made youths 'leaving the gendered routes suggested to them by ... dominant cultural norms', pointing to the significance of spaces for 'reflections beyond everyday life ... to reframe experiences and to reconstruct their transitional biography together with their gender biography' (p. 72). In addition, it showed the relevance of generous spaces and projects that support new gender behaviours. 


\section{Labour market and vocational studies}

Bringing the concept of biographical learning into the field of work and labour market research, Stroobants, Jans, and Wildemeersch (2001) consider the biographical learning process as concerning the relation between people and the world of work. The authors explicitly say they are following in the track of Alheit; however, they attempt to outline a conceptual framework of their own. This framework aims at understanding people's workrelated learning processes by recognizing how individuals 'create meaningful connections' between their own life and society. Even though the term biographical learning is left out in favour of transitional learning, the learning process presented emphasizes how people understand their own lives. In the suggested framework, people's action strategies are described within a scheme structured by two dimensions. One is about demands and calls attention to whether the personal or the societal demands are given priority. The other dimension concerns how the individual considers the options for changing arrangements and structures, whether those are 'changeable' or 'unchangeable'.

Starting from this model, the authors describe different action strategies that people use to 'make meaningful connections' between self and society, in order to deal with challenges related to work and employment. The authors argue that individual learning processes can be understood as 'processes of transitional learning aimed at creating meaningful connections between individual life and society via work and adult education' (p. 114). Further, the authors call for a reconsideration of the role of the adult educator. It is 'dramatically shifting' from distributing skills to facilitating learning, that is, they are no longer experts in only the labour market, but have to engage with problem solving. This in turn requires 'interpretive activities' in understanding and negotiating people's possibilities and limitations in the particular context of which they live, including understanding how people 'make sense of 
transitions in their own life, how they relate their own competencies as situated in their biographies to external opportunity structures' (p. 116).

In the field of vocational psychology, the concept of biographical learning has been viewed aside from other similar concepts to provide a basis for conceptual development in the field and to outline a new paradigm for career interventions (Savickas, 2012; Savickas et al., 2009). The main idea is that in the new 'individualized' and unstable world of work, people cope with changes and career transitions by remaking their biographies:
As individuals encounter changes in work roles ... using autobiographical reasoning enables [individuals] to make sense of new experiences and eventually master the vocational development tasks, occupational transitions ... In revising identity and career stories (whether through experience or through counseling), the self-as-process repeatedly reorganizes life experiences into narratives with increasing unity, continuity, purpose, and meaning. (Savickas, 2011, p. 27)

In the same way, Hallqvist (2012) suggests that work transitions can be conceptualized as a biographical learning process. The studies, however, do not elaborate on the interplay between social conditions and biographical constructions.

\section{Conclusions}

The concept of biographical learning thus occurs in different settings and in different versions. This is probably a strength because its not-yet-settled character promotes further development of the concept. As Clark and Rossiter (2008) point out, although narrative research has been on the move for some time, adult education has begun 'catching the wave relatively recently' (p. 61). Assuming that the concept of biographical learning is suited for adult education research, taking as a point of departure people's various experiences of lifediscontinuity, there are several new research areas that could be addressed in further studies. 
Migration is one of them. Bron (2000) has embarked on this task, but she has had no followers yet. In the field of career counselling, there is an emerging body of research that uses different concepts of narrative and narrative analysis (Cohen \& Mallon, 2001; Del Corso \& Rehfuss, 2011; LaPointe, 2010, 2013; Reid \& West, 2011; Savickas, et al., 2009) but they use the concept of biographical learning only occasionally. Besides issues related to disruptions and changes in people's professional career, it would be fruitful to address questions about transitions into and within the criminal career, including people's efforts to leave a criminal career and make the transition in to a non-criminal life-style. A related issue concerns addiction and recovery. These different topics mentioned all concern biographic disruption and change. This also suggests that a connection could be established between the concept of biographical learning and the more widespread concept of biographical disruption, originally developed by Bury (1982) but used and further developed by Williams (1984), Becker (1997), and several other authors.

The tensions I have pointed to above concern the following five themes: (1) the relation between action and sense making, (2) what should be considered the proper object of knowledge: one's action patterns (Biesta \& Tedder, 2007), one's biography (Alheit \& Dausien, 2002), or the relation between oneself and the social world (Alheit, 1994), (3) whether the learning process is characterized by people actively and consciously reflecting on their lives or whether the learning process rather is dependent on serendipity, chance, and self-regulation, which imagines a more passive learner, (4) whether the concept should focus on discourse or experience, and (5) a possibly over-optimistic character of biographical learning, a belief that stories can 'change structures'. Besides these tensions, there are reasons to discuss critically the idea regarding the occurrence of general conceptions of one's biography, as well as the idea of narrative coherence that is present in the biographical 
learning tradition. There is no consensus on whether the production of broad internalized and 'coherent' life stories is doable and if one's narrative identity really can be captured in a single synthesizing story. Perhaps one's stories are many and diverse (Raggatt, 2006), because storytelling is a social praxis and language is 'inherently indexical' (Mishler, 1979, p. 64). The concept of coherence in itself is rather ambiguous, but may be considered not only as a linguistic attainment but as achieved in the particular social and cultural situation (Mishler, 1999). When people in late modernity produce autobiographical accounts, almost certainly there will be a variety, for example, in terms of elaborateness (Goodson, Biesta, Tedder, \& Adair, 2010) and the temporal scope of people's career stories. And besides expecting general unifying stories, research should recognize minor context-specific autobiographical accounts by which the storyteller understands life events and everyday challenges - in order not to renounce tensions and ambiguities but to allow oneself to be aware of self as contradictory, moving outside 'humanism's boundaried individual' (Twomey, 2005), and thus not supressing intra-individual variety. 


\section{References}

Alheit, P. 1992. The biographical approach to adult education. In W. Mader (Ed.), Adult education in the Federal Republic of Germany. Scholarly approaches and professional practice (pp. 186-222). Vancouver: University of British Columbia/International Council for Adult Education.

Alheit, P. 1994. The 'biographical question' as a challenge to adult education. International Review of Education, 40(3), 283-298.

Alheit, P. 1999. On a contradictory way to the 'learning society': a critical approach. Studies in the Education of Adults, 31(1), 66-82.

Alheit, P. 2005. Stories and structures: An essay on historical times, narratives and their hidden impact on adult learning. Studies in the Education of Adults, 37(2), 201-212.

Alheit, P., Bron-Wojciechowska, A., Brugger, E., \& Dominicé, P. (Eds.). (1995). The biographical approach in European adult education. Vienna: Verband Wiener Volksbildung.

Alheit, P., \& Dausien, B. 2002. The double face of lifelong learning: Two analytical perspectives on a silent revolution. Studies in the Education of Adults, 34(1), 3-22.

Antikainen, A., \& Komonen, K. 2003. Biography, life course, and the sociology of education. In C. Torres \& A. Antikainen (Eds.), The international handbook on the sociology of education. An international assessment of new research and theory. (pp. 143-159). Lanham, MD: Rowman \& Littlefield Publishers.

Bauman, Z. 2000. Liquid modernity. Cambridge: Polity.

Becker, G. 1997. Disrupted lives: How people create meaning in a chaotic world. Berkeley, CA: University of California.

Biesta, G. 2009. Pragmatism's contribution to understanding 'learning-in-context'. In R. Edwards, G. Biesta \& M. Thorpe (Eds.), Rethinking contexts for learning and teaching: communities, activities and networks (pp. 61-74). New York: Routledge.

Biesta, G., \& Tedder, M. 2007. Agency and learning in the life course: Towards an ecological perspective. Studies in the Education of Adults, 39(2), 132-149.

Biesta, G., \& Tedder, M. 2008. Learning from life in the learning economy: The role of narrative. Paper presented at the 38th Annual Conference of Scutrea, University of Edinburgh, Edinburgh, UK.

Brockmann, M. 2010. Identity and apprenticeship: The case of English motor vehicle maintenance apprentices. Journal of Vocational Education \& Training, 62(1), 63-73.

Bron, A. 2000. Floating as an analytical category in the narratives of Polish immigrants to Sweden. In M. Bron, L. Sokół \& E. Szwejkowska-Olsson (Eds.), Allvarlig debatt and rolig lek [Serious debate and amusing play] (pp. 119-132). Uppsala: Centrum för multietnisk forskning.

Bron, A., \& West, L. 2000. Time for stories: The emergence of life history methods in the social sciences. International journal of contemporary sociology, 37(2), 158-175.

Bruner, J. S. 1986. Actual minds, possible worlds. Cambridge, MA: Harvard University Press.

Bruner, J. S. 1990. Acts of meaning. Cambridge, MA: Harvard

Bury, M. 1982. Chronic illness as biographical disruption. Sociology of Health \& Illness, 4(2), 167-182. 
Chamberlayne, P. 2004. Biographical methods and social policy in European perspective Biographical Methods and Professional Practice: An International Perspective (pp. 19-38). Bristol: Policy Press.

Chamberlayne, P., Bornat, J., \& Wengraf, T. 2000. The turn to biographical methods in social science: Comparative issues and examples. New York, NY: Routledge.

Christensen, M. K. 2007. Biographical learning as health promotion in physical education. A Danish case study. European Physical Education Review, 13(1), 5-24.

Christensen, M. K. 2011. Exploring biographical learning in elite soccer coaching. Sport, Education and Society, 10.1080/13573322.2011.637550, 1-19.

Clark, M. C., \& Rossiter, M. 2008. Narrative learning in adulthood. New Directions for Adult and Continuing Education, 2008(119), 61-70.

Cohen, L., \& Mallon, M. 2001. My brilliant career? Using stories as a methodological tool in careers research. International Studies of Management \& Organization, 48-68.

Del Corso, J., \& Rehfuss, M. C. 2011. The role of narrative in career construction theory. Journal of Vocational Behavior, 79(2), 334-339.

Diepstraten, I., du Bois-Reymond, M., \& Vinken, H. 2006. Trendsetting Learning Biographies: Concepts of Navigating through Late-modern Life and Learning. Journal of youth studies, 9(2), 175-193.

Dominicé, P. 2000. Learning from our lives. San Francisco: Jossey-Bass.

Field, J. 2010. Lifelong Learning. In P. Peterson, E. Baker \& B. McGaw (Eds.), International Encyclopedia of Education (3rd ed) (pp. 89-95). Oxford: Elsevier.

Fristrup, T. 2012. Gerontopedagogicalization: A critical approach to performAGE in later life. In J. Kornbeck \& N. Rosendal Jensen (Eds.), Social Pedagogy for the Entire Lifespan (Vol. 2, pp. 68-92). Bremen: EH Verlag.

Giddens, A. 1991. Modernity and self-identity: self and society in the late modern age. Stanford: Stanford Univ. Press.

Glastra, F. J., Hake, B. J., \& Schedler, P. E. 2004. Lifelong learning as transitional learning. Adult Education Quarterly, 54(4), 291-307.

Goodson, I. F., Biesta, G., Tedder, M., \& Adair, N. 2010. Narrative learning. London: Routledge.

Hall, D. T. 1996. Protean careers of the 21st century. The Academy of Management Executive (1993-2005), 10(4), 8-16.

Hall, D. T. 2004. The protean career: A quarter-century journey. Journal of Vocational Behavior, 65(1), 1-13.

Hallqvist, A. 2012. Work Transitions as Biographical Learning: Exploring the Dynamics of Job Loss. Linköping.

Hallqvist, A., Ellstrom, P. E., \& Hydén, L. C. 2012. The many faces of biographical learning. Studies in the Education of Adults, 44(1), 70-84.

Hallqvist, A., \& Hydén, L. C. 2013. Work transitions as told: A narrative approach to biographical learning. Studies in Continuing Education, 35(1), 1-16.

Herzberg, H. 2006. Learning habitus and the dynamics of lifelong learning. Studies in the Education of Adults, 38(1), 37-47.

Honneth, A. 1995. Struggle for recognition: the moral grammar of social conflicts. Cambridge: Polity Press.

Horsdal, M. 2012. Telling lives. New York: Routledge. 
Hydén, L. C. 2008. Berättelseforskning [Narrative research]. In A. Meeuwisse, H. Swärdh, R. Eliasson Lappalainen \& K. Jacobsson (Eds.), Forskningsmetodik för socialvetare. [Research methods for the social scientist]. Stockholm: Natur och Kultur.

Kristensson Uggla, B. 2008. Who is the lifelong learner? Globalization, lifelong learning and hermeneutics. Studies in Philosophy and Education, 27(4), 211-226.

Labov, W. 1972. Language in the inner city: studies in the black English vernacular. Philadelphia, PA: University of Pennsylvania Press.

LaPointe, K. 2010. Narrating career, positioning identity: Career identity as a narrative practice. Journal of Vocational Behavior, 77(1), 1-9.

LaPointe, K. 2013. Heroic Career Changers? Gendered Identity Work in Career Transitions. Gender, Work \& Organization, Volume 20, Issue 2, pages 133-146, March 2013(2), $133-146$.

Lischka, W. 1995. A new horizon for adult education research. In P. Alheit, A. BronWojciechowska, E. Brugger \& P. Dominicé (Eds.), The biographical approach in European adult education (pp. 57-74). Vienna: Verband Wiener Volksbildung.

Merrill, B., \& Alheit, P. 2004. Biography and narratives Researching Widening Access to Lifelong Learning: Issues and Approaches in International Research (pp. 150-162). Abingdon: Routledge.

Mishler, E. G. 1979. Meaning in context: Is there any other kind? Harvard Educational Review, 119(1), 1-19.

Mishler, E. G. 1995. Models of narrative analysis: A typology. Journal of Narrative \& Life History, 5(2), 87-123.

Mishler, E. G. 1999. Storylines: craftartists' narratives of identity. Cambridge: Harvard University Press.

Prescott, L. 2011. Life writing and life-learning: an analysis of creative writing students work. Studies in Continuing Education, 34(2), 145-157.

Raggatt, P. T. F. 2006. Multiplicity and Conflict in the Dialogical Self: A Life-Narrative Approach: American Psychological Association.

Reid, H., \& West, L. 2011. Telling tales: Using narrative in career guidance. Journal of Vocational Behavior, 78(2), 174-183.

Ricœur, P. 1991. From text to action. Evanston, Ill.: Northwestern University Press.

Ricœur, P. 1992. Oneself as another. Chicago, IL: University of Chicago Press.

Sarbin, T. R. 1986. The narrative as root metaphor for psychology. In T. R. Sarbin (Ed.), Narrative psychology: the storied nature of human conduct. New York: Praeger.

Savickas, M. L. 2011. The self in vocational psychology: Object, subject, and project. Paper presented at the 8th Biennial Meeting of the Society for Vocational Psychology, Akron, $\mathrm{OH}$.

Savickas, M. L. 2012. Life Design: A Paradigm for Career Intervention in the 21st Century. Journal of Counseling \& Development, 90(1), 13-19.

Savickas, M. L., Nota, L., Rossier, J., Dauwalder, J. P., Duarte, M. E., Guichard, J., . . van Vianen, A. E. M. 2009. Life designing: A paradigm for career construction in the 21st century. Journal of Vocational Behavior, 75(3), 239-250.

Stauber, B. 2006. Biography and gender in youth transitions. New Directions for Child and Adolescent Development, 2006(113), 63-75.

Stroobants, V. 2005. Stories about learning in narrative biographical research. International Journal of Qualitative Studies in Education, 18(1), 47-61. 
Stroobants, V., Jans, M., \& Wildemeersch, D. 2001. Making sense of learning for work. Towards a framework of transitional learning. International Journal of Lifelong Education, 20, 1(2), 114-126.

Taylor, C. 1989. Sources of the self: the making of the modern identity. Cambridge: Cambridge Univ. Press.

Tedder, M., \& Biesta, G. 2007. Learning from life and learning for life: Exploring the opportunities for biographical learning in the lives of adults. Paper presented at the ESREA Conference on Life History and Biography, Roskilde.

Tedder, M., \& Biesta, G. 2009. Biography, transition and learning in the lifecourse. The role of narrative. In J. Field, J. Gallacher \& R. Ingram (Eds.), Researching transitions in lifelong learning (pp. 76-90). Abingdon: Routledge.

Twomey, S. 2005. Disappearing acts: resuscitative reflections on the academy. Gender and Education, 17(3), 333-341.

West, L. 2010. Adult learning in a biographic perspective. In P. Peterson, E. Baker \& B. McGaw (Eds.), International encyclopedia of education (3rd ed.) (pp. 25-30). Oxford: Elsevier.

West, L., Alheit, P., Andersen, A. S., \& Merrill, B. (Eds.). (2007). Using biographical and life history approaches in the study of adult and lifelong learning: European perspectives. Frankfurt: Peter Lang.

Williams, G. 1984. The genesis of chronic illness: narrative re construction. Sociology of Health \& Illness, 6(2), 175-200.

Zeller, M., \& Köngeter, S. 2012. Education in residential care and in school: A socialpedagogical perspective on the educational attainment of young women leaving care. Children and Youth Services Review, 34(6), 1190-1196. 